\title{
Domestication of Non-Conventional Crops to Combat Human Health Diseases: A Review on Crop Stevia Rebaudianain View of Pakistan as an Example
}

\author{
Muhammad Saqib ${ }^{3}$, Muhammad Ijaz ${ }^{2}$, Muhammad Latif ${ }^{3}$, Khalid Mahmood 1 , Tauqeer \\ Ahmad Yasir ${ }^{2}$ \\ ${ }^{1}$ Department of Agro-ecology, Faculty of science and technology, Aarhus University, Denmark \\ ${ }^{2}$ College of Agriculture, Bahauddin Zakariya University, Bahadur Sub Campus Layyah, Pakistan \\ ${ }^{3}$ Department of Agronomy, the Islamia University Bahawalpur, Pakistan
}

\begin{abstract}
In developing countries health diseases such as diabetes and obesity are increasing at alarming rate. One of the major reason is an excessive use of sucrose (Sugar) obtained from the extract of Sacharum Officinarum and Beta vulgare. Sugar serves as a toxin if consumed in excessive amount and disrupt the body's usual hormonal cycles. Being integral part of our food system, it is not possible to eliminate the consumption of sugar from our routine life. Under such circumstances, there is a need to find an alternative sugar crop having less dreadful effects on the health of the human. Stevia rebaudiana, a zero or less caloric crop sweetener, is already widely being used as an alternative crop in many regions of the globe. The future of this plant is promising in Pakistan. However more research is needed to confirm its adaptability and economicsin various regions of Pakistan. This review paper provides comprehensive information about taxonomy, history, origin, ecological requirement, botanical description, chemical properties, and importance of Stevia rebaudiana. The major aim of this review paper is to encourage the cultivation of Stevia rebaudiana as sugar alternative crop through awareness and acceptance of this crop among sugar producers and consumers as a new promising sugar crop.
\end{abstract}

Keywords: Crop domestication, ecological requirements, health diseases, food system, Stevia rebaudiana, sugar,

\section{INTRODUCTION}

Genus Stevia, Asteraceae family, comprises about 230 different species involving both annual and perennial herbs, subshrubs and shrubs that mostly grow in mountainous areas, forests, river boarders and dry vallies(Frederico et al., 1996; Guleria \& Yadav, 2013).Of these 230 species only two species, S. rebaudiana and S. phlebophylla, possesses the relatively high amount of steviol glycosides (SGs) responsible for the sweet taste (Savita et al., 2004b; Brandle \& Telmer, 2007; Prakash et al., 2008; Gupta et al., 2013; Shivanna, 2013;).

Stevia rebaudiana is a perennial shrub mostly grown in tropical and sub-tropical climatic regions and is native to South Africa particularly Paraguay (Mizutani \& Tanaka, 2002).From hundreds of years, its dry leaves have been used as natural sweating agent having relatively 7-15\% high concentration of steviol glycosides (Chaturvedula, et al., 2011; Carakostas et al., 2011). Amongst these steviol glycosides, Stevioside (60-70\% of total SGs) and rebaudioside-A (15-20\% of total SGs) are more important in spite of other SGs e.g. steviolbioside, rebaudioside-C, rebaudioside-D, rebaudioside-E, rebaudioside-F and ducloside-A (Bhimba et al., 2010; Crammer and Ikan, 1986).

Nowadays, $S$. rebaudiana is getting more interest in several countries as an alternative sugar crop and is widely used in most of the part of the world by diabetic people or who need fewer calories. In 2009, highly purified steviol glycosides received the GRAS (Generally Recognized as Safe) status in USA (Jaworska et al., 2012) and are also approved as food additive in USA, UK, China, Japan, Korea South America, Mexico, Indonesia and Canada (Bondarev et al., 2003; FSANZ, 2008; Wolwer-Rieck, 2012; Dey et al., 2013a).

Studies exposed the importance of Stevia rebaudiana as low or non-caloric, non-toxic and non-mutagenic ingredient (Sekihashi et al. 2002; Mizutani and Tanaka, 2002;Kim et al., 2002) and its utilization thoughtout the world especially in USA, Spain and France as sugar Substitute as well as in beverages, wine making, fruit drinks, cosmetics and bakery products (Kinghorn, 2002; Gregersen et al., 2004; Chatsudthipong \& Muanprasat, 2009; Wolwer-Rieck et al., 2010; Goyal et al. 2010; Stoyanova et al., 2011). Production of Stevia rebaudiana is spread to

${ }^{1}$ Corresponding Author: khalid.mahmood@agrsci.dk 


\section{American Research Journal of Agriculture, Volume 1, Issue 1, February 2015}

ISSN 2378-9018

different countries of the world including Canada and specific regions of Europe and Asia (Amzad-Hossain et al., 2010; Gardana et al., 2010).

Dry leaves of Stevia rebaudiana are300 to450 times more sweet than sucrose (Chang et al., 2007; Yu and Shi, 2009; Silvia \& Luciana, 2013) and also contain flavonoids, vitamins, tannins, phytosterols, minerals, alkaloids, hydroxycynnamic acid, essential oils and other miscellaneous compounds with antimicrobial as well as antioxidant properties (Tadhani \& Subhash, 2006; Tadhani et al., 2007; Darabpour et al., 2010; Muanda et al., 2011; WolwerRieck, 2012; Lemus-Mondaca et al., 2012; Belda-Galbis et al., 2014;).

Consumption of dry leaves of Stevia rebaudiana positive influences the human health by regulating hypotension, enhancing antiglycaemic activity, preventing dental cavity, decreasing heart rate or improving digestion and gastrointestinal functioning (Lee et al, 2001; Midmore \& Rank, 2002; Jeppesen et al., 2003; Gupta et al., 2013).Sweeteners usually used such as table sugar and maple sugar are consist of glucose, sucrose and fructose primarily produced from sugarcane (Sacharum Officinarum) with a small contribution of sugar beet (Beta vulgaris) (Savita et al., 2004a).

Main drawback of these sweeteners is that they highly contributes to calories and have dreadful effects on human health and body weight. Excessive energy from sucrose is stored by the body in the form of fat that ultimately increases the chances of several diseases like obesity as well as subsidizes to cancer, diabetes hypertension and cardiovascular diseases (Pearson, 200; Savita et al. 2004b; Bopp \& Prince, 2001). During the year 2012-13, worldwide production of cane sugar was $180.837 \mathrm{MT}$ and its consumption was $176.33 \mathrm{MT}$. The production of cane sugar has been of the order of 5.03 MT tones and that of beet sugar 0.033 thousand tones in Pakistan (PSMA, 2013).

Currently, about 0.382 billion people in the world are suffering from diabetes which might increase to 0.592 billion by year 2035 (Guariguata et al., 2014) and in 2030 the seventh most leading cause of death will be diabetes (Kelly et al., 2008). According to the International Diabetes Federation (IDF), about 6.713 million people suffers from the dreadful disease called diabetes in 2013 which will possibly increase to 12.798 million in 2035 (Guariguata et al., 2014), whereas, Global Burden of Disease Study, rank Pakistan at number 9 out of 188 countries in terms of obesity (Ng et al., 2014).

Most of western countries of the world consume products produced from medicinal or functional plants such as natural food increments or herbal tonics that promotes good human health is increasing and getting solid interest (Goldberg, 1994; Boue et al., 2009). Such natural food products can be used as an appreciated tool in the avoidance and control of such diseases like obesity, cardiovascular disease, diabetes, cancer and other related diseases increasing drastically in many countries of the world. .

Researches revealed that secondary metabolites present in Stevia rebaudiana have no teratogenic, mutagenic or carcinogenic effects and doesn't have allergic reactions if consumed as a sweetener (Pol et al., 2007). For this reason, use of Stevia rebaudiana as a low-calorie sweetener alternative to sucrose can led to the development of new natural sugar product thus improves many aspects of human health in the treatment of obesity, diabetes, hypertension and cardiovascular diseases by reducing calories (Chen et al. 2006; Boue et al., 2009). Therefore, we presented a review paper on its potential as an alternative sugar crop in order to create awareness about this species among sugar producers and consumers for its acceptance thereby making contribution in enhancing its importance as a new promising sugar crop.

\section{TAXONOMY}

Stevia rebaudiana belongs to the Class Magnoliopsida, Suborder Asteranae, Order Asterales, subtribe Ageratinae, and tribe Eupatorieae (Newell-McGloughlin, 2008; Guleria \& Yadav, 2013; Kumari \& Chandra, 2013). Spanish Botanist \& Physicist, P. J. Esteve first discovered genus Stevia in the 16th century. Dr. Moisés Santiago Bertoni was the first person who discovers this plant in 1888 in Paraguay. Rebaudiana, the species name, credited in honor of the French Chemist Dr. Rebaudi, who first identified the sweetening substance in the plant, in 1905. Earlier, it was botanically classified as Eupatorium rebaudianum Bertoni but later it was changed to S. rebaudiana Bertoni. Stevia rebaudiana in Guarani language of its native area, Paraguay, is commonly known as "Caá hê-é" means sweet herb (Soejarto, 2002).

\section{HISTORY}

Leaves of Stevia rebaudiana were firstly used as sweeten mate or as a general sweetening agent by native people of Paraguay and Brazil (Soejarto, 2002; Sehar et al., 2008). M. S. Bertoni, a European Botanist, in 1887 first to 
document Stevia rebaudiana (Schreiber, 2010) and French chemists Dr. Rebaudi in 1905, extracted different sweetening agents like rebaudioside \&stevioside, the main sweet element in the form of white crystalline compound (Puri et al., 2011). Subsequently, Stevia rebaudiana was utilized as a sweetening agent intended for food shortages during World War II when sugar again became unavailable (Small et al., 2001; LeCroy, 2014).

In 1942, an unsuccessful attempt to establish Stevia rebaudiana as a crop was made in England. But in 1964, its first commercial cultivation was reported in Paraguay (Katayama et al. 1976; Lewis 1992). Afterward, great efforts were made by Sunida in 1968 to establish Stevia rebaudiana cultivation in Japan. In 1971, researches were conducted to evaluate the potential of Stevia rebaudiana in Japan (Crammer \& Ikan, 1986) and today Japan is the major grower as well as marketer of Stevia rebaudiana in all over the world (Ramesh, 2006). Later on, it was introduced as a crop in a many countries including Brazil, Canada, Indonesia, Korea, Mexico, Tanzania and United States (Yadav et al., 2011) Fors 1995). Presently, China is the largest producer of Stevia rebaudiana and its major market is in Japan with an estimated market value of around 2-3billion yen/yr (Kinghorn \& Soejarto 1985). Stevia rebaudiana is getting attention with the increase in demand for low carbohydrate and low calories alternative sugar crop in order to control obesity, diabetes and high blood pressure.

Nowadays, it is adapted as an alternative sugar crop in countries including Belgium, Central America, China, Japan, Mexico, Malaysia, Paraguay, Spain, South Korea and UK (Williams \& Burdock, 2009; Puri et al., 2011). It is expected that in future Stevia rebaudiana will overhaul the status of sucrose because of its safety and therapeutic values against several harmful ailments

\section{ECOLOGY}

Stevia rebaudiana, native to the tropical regions of Brazil and Paraguay, occurs naturally in subtropical regions on the boundaries of marshlands or in grassland up to the elevation of $700 \mathrm{~m}$ (Yadav et al., 2011). In the tropics regions it can be grown at altitudes up to $1500 \mathrm{~m}$. Stevia rebaudiana can grow best in semi-humid sub-tropical areas with an annual rainfall of $1500-1800 \mathrm{~mm}$, temperature of $21-43^{\circ} \mathrm{C}$ for its normal growth (Huxley, 1992). It cannot tolerate extreme cold conditions and temperature below $9^{\circ} \mathrm{C}$ cease down the normal functions of Stevia rebaudiana (Singh \& Rao, 2005).

Stevia rebaudiana can be grown in areas with wide range of soil having $\mathrm{pH}$ ranging from 6.5-7.5 (Chalapathi, 1999) but usually prefers a sandy soil, requiring a warm sunny position (Midmore \& Rank, 2002). It needs a critical photoperiod of 12 hours to initiate flowering usually 40-60 days after flowering. However, increase in day-light duration promotes production of leaves which ultimately results in higher stevioside contents. Stevia rebaudiana shows better results when grown as a crop in fertile fields (Oddone B., 1999). It requires regular supply of water for its normal vegetative growth which might results in permanent wilting of Stevia rebaudiana leaves therefore it must soil must be well drained in order to prevent such losses (Chalapathi, 1999). An optimum ecological criterion for the cultivation of Stevia rebaudiana is shown in Table. 1.

An ecological study of Stevia rebaudiana shows that it can be successfully adapted as an alternative sugar crop in subtropical areas of Pakistan. These areas meet the ecological criteria for Stevia rebaudiana cultivation and untidy topography might help in the drainage of water which will diminish the risk of permanent wilting.

\section{BIOLOGY}

\subsection{Botany}

Stevia rebaudiana is a short day plant that can grow up to the height of 2-6 feet approximately forming a vigorous shallow root network (Woelwer-Rieck et al., 2010). Its growth is totally dependent on existing weather conditions. Growth pattern of Stevia rebaudiana is divided into 4 different stages, germination and seedling establishment, vegetative growth, floral bud initiation, pollination to fertilization and seed growth and maturity (Ramesh et al., 2006). Stevia rebaudiana form abundant stock of fibrous and filiform perennial roots that hardly reaches the land surface and have zero stevioside (Zaidan et al., 1980; Ramesh et al., 2006). Taiari et al, 2004 stated that Stevia rebaudiana form a structure of fine roots near the soil surface and thick roots structure in deep zone. Stem of Stevia rebaudiana is annual, sub-ligneous and pubescent (Ramesh et al., 2006). Its leaves are $3-8 \mathrm{~cm}$ long and $1-2 \mathrm{~cm}$ wide having lanceolate to oblanceolate shape, with fine saw-like margin and are arranged alternatively (Dwivedi, 1999). Small sized self-incompatible florets $(7-15 \mathrm{~mm})$ of Stevia rebaudiana are white in color with purplish throat, arranged in irregular corymbs form having 2-6 florets (Dwivedi, 1999; Singh \&Rao, 2005; Yadav et al., 2011). Plant completes its flowering period within a month (Ramesh et al., 2006). Seed of Stevia rebaudiana is an achene of 3 
$\mathrm{mm}$ length has 20 feathery pappus (Pedroza Carneiro, 2007). Seed of Stevia rebaudiana are usually infertile thus it shows a very poor percentage of germination (Carneiro et al., 1997; Lemus-Mondaca et al., 2012).

\subsection{Seed Germination}

Seeds of Stevia rebaudiana are smaller in size and it usually shows a very poor germination percentage (Singh \& Rao, 2005). Thus, cultivation of Stevia rebaudiana through seeds is not an adequate approach because its germination varies greatly (Taware et al., 2010; Yadav et al., 2011). Lemus-Mondaca (2012) stated that one of the major limiting factors in the cultivation of stevia is poor seed germination. Therefore, the propagation through cutting and tissue culture is usually considered as an effective approach for cultivation of Stevia rebaudiana on a large scale (Chalapathi \& Shivraj, 1997).

\subsection{Propagation}

Traditionally, propagation of stevia was done through cutting, an instable, unreliable and less productive method, which takes a lot of time, labor and cost (Karim et al., 2013). Hence, there is a crucial need to develop method for rapid multiplication of Stevia.

\subsection{Cutting}

Propagules obtained as the result of stem cuttings usually shows unpredictable and unstable outcomes. Chalapathi (1999) reported that pre-treatment of cutting $(15 \mathrm{~cm})$ with Paclabutrazol at the rate of 50-100ppm showed good effect on the sprouting and rooting of Stevia rebaudiana. In order to achieve good rooting results, cuttings from the main stem should be used for vegetative propagation and must be treated with growth regulators for adequate rooting (Bondarev, 1998; LeCroy, 2014). Therefore, in order to cop such type of restrictions associated with traditional propagation method of Stevia rebaudiana cultivation, development of micro-propagation through axillary buds and shoot tips played their effective role in its rapid multiplication.

\subsection{In-Vitro Cultures}

For the preparation of adequate stock in short time, require enough labor and stem cuttings are required for the cultivation of Stevia rebaudiana on a large scale (Carneiro et al., 1997). In this context, production of adequate plantlets is only possible through a reliable substitute technique such as in-vitro cultures e.g. shoot tip, axillary buds (Sivaram and Mukundan, 2003; Anbajhagan et al., 2010; Taware et al., 2010; Jagatheeswari and Ranganathan, 2012; Sabah and Rasha, 2013). Micro-propagation helps in recovering a genetically stable and true-to-type progeny and also helps in restoring important Germplasm (Thiyagarajan \& Venkatachalam, 2012). Reports on the in-vitro cultures exist as a convenient method through leaves, nodes, internodes and shoot tips for large scale cultivation (Salim et al., 2006; Thiyagarajan \& Venkatachalam, 2012).

\section{Status In Pakistan}

Stevia rebaudiana, a natural sweet herb, is cultivated as an alternative sugar crop and cash crop in different countries on the globe. Cultivation of Stevia rebaudiana on a large scale faces a problem because of its poor seed germination. Therefore, unavailability of mechanized production technology is biggest hurdle in the domestication of Stevia rebaudiana (Savita et al., 2004a). In Pakistan, Stevia rebaudiana was introduced through tissue culture technique during the year 2003 (Talha et al., 2012).It cultivation is still limited to research and is not cultivated as a cash crop or alternative sugar crop(Fazal et al., 2011).Rafiq et al. (2007) instead of having a very diverse weather conditions still there is no literature on the cultivation as well as in-vitro propagation of Stevia rebaudiana on commercial level of Stevia rebaudiana in Pakistan. However, Pakistan Agricultural Research Council (PARC) and Punjab Agricultural Research Board (PARB) have approved several research proposals for the present and future scenarios on the development and dissemination of information about $S$. Rebaudiana cultivation in various regions of Pakistan

\section{Production Technology}

\subsection{Sowing Time}

Nursery of stevia can be prepared usually through seed, cuttings and tissue culture in Pakistan.Plants prepared from seeds are transplanted to field after 2 months, whereas, seedlings from tissue culture or cuttings can be transferred after one month. For spring cultivation, nursery should be sown in December-January and should be transplanted to field in February. For Rabi cultivation, nursery should be sown in August-September and transplanted to field in October-November. 


\section{American Research Journal of Agriculture, Volume 1, Issue 1, February 2015}

ISSN 2378-9018

\subsection{Nursery Sowing}

For good germination, only dark brown or black colored seeds should be used for nursery sowing. Seeds should be sown in plastic bags or pots filled with equal amount of thoroughly mixed sand, silt, clay and organic matter. After sowing, cover the seeds with a thin layer of soil, and then sprinkle some water to facilitate germination. Bags or pots should be covered in order to conserve moisture. Light Irrigation with the help of sprinkler should be done at the suitable interval of one to two weeks until maximum germination is obtained. For cuttings, stem of $4 \mathrm{~cm}$ height containing axillary buds should be sown in a plastic cup up to a depth of 1 to $2 \mathrm{~cm}$ and then irrigate it. After that, cover the plastic cupswith polythene sheet and place it at $15-20^{\circ} \mathrm{C}$. When the cut-lings get ready, transfer it to the field.

\subsection{Land Preparation}

Field should be plowed or cultivated twice to prepare a fairly, firm and smooth planting surface. The soil should be well pulverized and thoroughly mixed with organic matter, potassium and phosphorus fertilzers.

\subsection{Nursery Transplantation:}

After 15 days, remove the plastic bags containing cut-lings from the pots andplace them under a covered place to make them hardy. This is necessary for the young seedlings to tolerate the climatic conditions and grow further. To obtain optimum plant population the seedlings should be planted at row to row distance of $45 \mathrm{~cm}$ and plant to plant distance of $30 \mathrm{~cm}$. After the completion of transplantation, irrigate the field to ensure optimal crop stand.

\subsection{Fertilizer \& Irrigation Scheduling:}

Two bags of Urea (50 Kg per bag), one bag of DAP (50 Kgper bag), and one bag of Ammonium Sulphate (50 Kg per bag)should be applied to obtain good economic leaves yield. Field should be light irrigated 1-2 times in a week.In summer season, especially June and July, light irrigation should be applied. Excessive water around the root for a long period may result in the yellowing of leaves due to suffocation and increase the chances of fungus diseases attack.

\subsection{Disease \& Insect}

Stevia is usually attacked by termites, sucking insects (Thrips, Aphids, and Jassids), American worm, and mealy bug. But these insect doesn't cause severe damage to Stevia. In case of severe attack, following chemicals should be used

\subsection{Termites}

Termites usually attack in dry conditions. For the control of termites Chlorpyrifos (O,O-diethyl O-3,5,6trichloropyridin-2-yl phosphorothioate) 40.I.C at the rate of 2 liters per acre should be applied with irrigation water.

\subsection{Sucking Insects}

For the control of sucking insects, Imidacloprid (200 SL) at the rate of $200 \mathrm{ml}$ or Acetamiprid (20SP) at the rate of $150 \mathrm{gm}$ in suitable quantity of water should be sprayed. For controlling mealy bug, Profenofos at the rate of 1 liter per acre should be sprayed.

\subsection{American Worm}

American worm should be controlled by spraying $150 \mathrm{ml}$ per acre Laporan in 100 liters of water.

\subsection{Root Rot}

$400 \mathrm{~g}$ Topsin in 100 liter of water should be sprayed near the roots. Because itusually attack on the roots of emerging seedlings

\subsection{Harvesting}

Leaves should be harvested before flowering in order to obtain high concentration of sweetening agents known as "Steviol glycosides".

\subsection{Yield}

18-22 mounds dry leaves per acre.

\subsection{Reference}

Akram et al. (2013) 


\section{Chemical \& Nutritional Properties}

Apart from these sweetening glycosides, Stevia rebaudiana is famous because of its chemical and nutritional properties i.e. amino acids, minerals and phytochemicals (Chu et al., 2000; Edeoga et al., 2005; Singh \& Rao, 2005). Leaves of Stevia rebaudiana also contain flavonoids, gums, inorganic matter, pigments, sterebins A to $\mathrm{H}$, triterpenes and volatile oil constituents (Brandle et al., 1998). Dry leaves of Stevia rebaudiana provide a strong basis of carbohydrate, protein, and crude fiber in maintaining good human health (Savita et al., 2004a; Abou-Arab et al., 2010; Mishra et al., 2010; Goyal et. al, 2010; Lemus-Mondaca et al., 2012).

Abou-Arab et al. (2010) stated that Stevia rebaudiana act as a good source of nutrients/minerals (Table. 2.) e.g. Phosphorus, Potassium, Sodium, Calcium, Iron, Zinc, and Magnesium as well as a valuable source of essential amino acids (Table. 3.), required for improving defense mechanism of body, regulating and maintaining several metabolic processes (Savita et al., 2004a; Lemus-Mondaca, 2012). Leaves of Stevia rebaudiana comprises number of different types of essential oils (Table. 4.), usually referred as "Life force" of a plant (Yadav \& Guleria, 2012).

\section{THERAPEUTIC ACTIVITIES}

Addition to lessor Non-caloric sweetness, Stevia rebaudiana also have other some therapeutic properties accompanied by related compounds such as sweet diterpene glycosides (Rebaudioside A, Steviol and Isosteviol), alkaloids, flavonoids, amino acids, hydroxycynnamic acids (Caffeic, Chlorogenic), lipids, water-soluble oligosaccharides, free sugars, essential oils and trace elements (Komissarenko et al., 1994; Hossain, 2012). These compounds possess anti-diarrheal, anti-hypertensive, anti-cariogenic, anti-carcinogenic, anti-inflammatory, antidiabetic, diuretic, and immune-modulatory properties (Goyal et al., 2010). As compare to the other natural and artificial sweeteners, Stevia rebaudiana possesses significant pharmaceutical values (Anton et al., 2010).

\subsection{Anti-Diabetic Activity}

Diabetes is usually caused by insulin abnormality, pancreatic dysfunction and glucose excess (Leahy, 200; ADA, 2010). Diabetic nephropathy is usually done in the treatment of chronic diabetes but it leads to development and spread of small blood vessels which ultimately leads to cardiovascular diseases (Ziegler, 2008). Beside these effects, none of the single oral anti-diabetic agent can maintain euglycemia and other cardiovascular diseases on long term basis (Shivanna et al., 2013). Under such conditions, Stevioside can be used as an alternative medicine and also as an excellent source for nutraceuticals (Dey et al., 2013b).Stevioside has a significant effect on glucose metabolism by reducing blood glucose level in patients suffering from type 2 diabetes Moreover, by the action on beta cells it enhances the secretion of insulin thus helps in the efficient recovery of diabetic patients (Dyrskog et al., 2005). The main activity of this anti-diabetic agent is to energize the beta cells of pancreas, enhance insulin sensitivity and stimulate supplementary insulin synthesis (Jeppesen et al., 2000). Leaf Extracts of Stevia rebaudiana also increase ability of glucose tolerance in humans (Chen et al., 2005; Gregerson et al., 2004; Anton et al., 2010).In South America, extract of Stevia rebaudiana is being used from many decades as an anti-diabetic agent (Jeppesen et al., 2002).

\subsection{Anti-Oxidant Activity}

Energy production for human biological metabolism is totally dependent on the oxidation process. During this process, molecular oxygen, by generating reactive oxygen species (ROS) reduces into water such as O2-, OH-, H2O2, RO., ROO. and R. (Apel \& Hirt, 2004). These ROS are involved in the initiation of many diseases like arthritis, cancer, cardiovascular disorder, diabetes, inflammation, immune deficiency, neurologic disorder etc (Parejo et al., 2002; Hou et al., 2003; Valko et al., 2007; Kim et al., 2011). For the assassination of such conditions, natural foods and medicinal plants, having the ability to scavenge free radicals, are utilized as an anti-oxidant (Hou et al., 2003; Galvez et al., 2005). Stevioside present in leaves of Stevia rebaudiana may act as a potential source as a natural antioxidant (Jahan et al., 2010). Diversity of antioxidants including, opigenin, kaempferol and quereitrin are present in leaf extract of Stevia rebaudiana that have the inhibiting ability against damage of DNA strand. Isosteviol, derived from stevioside, can reduce the generation of ROS by inhibiting the angiotension-II-induced cell proliferation and endothelin-1 secretion (Ghanta et al., 2007; Stoyanova et al., 2011). Isosteviol also improves the antioxidant defense in the adipose tissue and the vascular wall by inhibiting the atherosclerotic plaques development or by stabilizing of induction plaque (Geeraert et al., 2010). A phytochemical namely polyphenols play an important role in enhancing the antioxidant activity of this plant (Chatsudthipong \& Muanprasat, 2009; Ahmad et al., 2010)

\subsection{Anti-Microbial Activity}

Plant extracts and phytochemicals e.g. terpenes, tannins and flavonoids, present in Stevia rebaudiana can play a significant role as an anti-microbial agent in the cure of several clinical problems (Dabur et al., 2004; Debnath, 
2008; Darabpour et al., 2010). These phytochemicals are present in rich amount and are aesthetic, antiinflammatory, austroinullin and cardio-tonic in nature (Hossain, 2012). Octa-acetylombuoside, ombuine and retusine derived from stevioside show antimicrobial agent against few types of gram-positive \& gram-negative bacteria (Tomita et al., 1997). Vitery et al. (2010) verified this statement by detecting that leaves extract of Stevia rebaudiana showed inhibitory effect on gram positive bacteria (B. subtilis, S. aureus, M. letus, B. megaterium), Gram negative bacteria (S. marcensens, P. aeruginosa, E. coli, P. valgaris) and fungus (R. oligosporus and A. niger). However, it also has inhibitory effect on the binding abilities of several antibodies (Takahashi et al.2001). Siddique et al., (2014) found that leaves extract of Stevia rebaudiana containing $n$-hexane have dreadful effect on several animal pathogens (S. aureus) and is influential enough in controlling several food spoiling fungus (A. niger) \& Bacteria (S. aureus). Thus, it can be used as natural food preservative ingredient.

\subsection{Anti-Cariogenic Activity}

Stevia rebaudiana as a sweetener possesses an anti-cariogenic properties (Abu-Elteen, 2005; Chatsudthipong and Muanprasat., 2009). Streptococcus sobrinus is usually considered as a major agent involved in the development of all tooth decay and gingivitis (Okada et al., 2005). However, portion of S. mutans and L. acidophillus present in the plaque and saliva are directly responsible in increasing the incidence and activity of tooth decay (Thylstrup \& Fejersko, 2000). Leaf extract of Stevia rebaudiana obstructs the cariogenic property of Streptococcus sobrinus (Brambilla et al., 2014) and found effective along with hexane impeding the growth of S. mutans and L. acidophilus and retard plaque deposits (Contreras, 2013).

\subsection{Anti-Hypertensive Activity}

Stevia rebaudiana is also considered as an effective, reliable and alternative therapy in lowering the blood pressure level of patients suffering with hypertension (Brahmachari et al., 2011). Stevioside extracted from the leaves of Stevia rebaudiana perform an activity of complete vasodilator and has positive role in hypertension for its vasodilator activity (Goyal et al., 2010).It acts as anti-hypotensor which causes vasorelaxation by inhibiting the Ca2+influx in the blood vessels (Liu et al., 2002; Ulbricht et al., 2010). It induces diuresis and natriuresis without disturbing the renal plasma flow and cardiac frequency (Melis et al., 2009; Brahmachari et al., 2011). But comparable to other anti-hypotensive drugs its hypotensive effect is not even better than them (Liu et al., 2002). Stevioside at the rate of $0.75-1.5 \mathrm{~g} /$ day reduces the systolic blood pressure by $10-11 \mathrm{mmHg}$ and diastolic blood pressure by $6-14 \mathrm{mmHg}$ within the 1st week of treatment (Ferri et al., 2006; Maki et al., 2008).

\subsection{Anti-Carcinogenic Activity}

Paul et al. (2012) stated that leaf extract of Stevia rebaudiana action as an inhibitor in preventing the initiation and promotion of tumors. Stevioside, rebaudioside A \& C and ducloside A possesses analogous activities in the promotion of TPA (12-O-Tetradecanoylphorbol-13-Acetate), effective cancer therapeutic agent, like other triterpenoids used in the treatment of various types of Cancer (Yasukawa et al., 2002; Raskovic et al., 2004).

\subsection{Anti-Diarrheal Activity}

Stevioside presents in the dry leaf extract of Stevia rebaudiana obstruct the contraction and relaxation of smooth intestinal muscle linked with hypermobility-associated diarrhea (Shiozaki et al., 2006). Additionally, the dihydroisosteviol, assumed as a CFTR inhibitor which might be used in the formation of anti-diarrheal agent, lessens the discharge of intestinal fluid (Brahmachari et al., 2011).

\subsection{Anti-Inflammatory \& Immunomodulatory Activity}

Inflammation, either acute or chronic, is a usual response in mammalian tissue in which outer covering of a skin change in the form of painful swell due to injury or any other agent (Jain et al., 2011). ROS act as an inflammatory mediator in extending inflammatory responses and cell injury (Garcia et al., 2003). The phytochemicals present in the extract of Stevia rebaudiana possesses antioxidant properties which help in reducing inflammation (Bairagi et al., 2012). Stevioside reduces the production of inflammatory mediators by interfering with signaling pathway (Boonkaewwan et al., 2006). Arya et al., 2012 stated that the methanolic extract of Stevia rebaudiana showed potential as an anti-inflammatory agent.

\section{WOund Healing ACTIVITY}

Dry leaf extract of Stevia rebaudiana is used in eliminating blemishes, cleansing acne, elasticizing skin and fastening of wound healing process if few drops are applied on cuts and scrapes as topical wound dresser (Barathi, 2003; Bolaños \& Ramírez, 2007). 


\section{NeUrological ACTIVITY}

Leaf Extract of Stevia rebaudiana possesses the ability to create liveliness and comfort in addition to decrease in the desires of eating sweets, fast food, consumption of tobacco and alcoholic drinks (Durán et al., 2012. Sharma et al. (2010) observed that stevioside present in the Stevia rebaudiana possesses anti-amnesia properties asserting a protective effect on memory deficits.

\section{OBESITY CONTROL}

Most of the bakery, beverages and confectionary products are overloaded with sucrose which ultimately leads to overweight or obesity (Murphy, 2001). Stevia rebaudiana enclose no or less calories and is considered ideal for people aiming to loss or maintain their weight in the form dietary supplement (Park \& Cha, 2010). Steviol glycoside extracted from leaves of Stevia rebaudiana fulfills the desire of sweet taste without gaining extra weight. Use of Stevia rebaudiana in bakery, beverages and confectionaries will help in the loss and maintenance of weight much easier than before (Bharat et al., 2013).

\section{UNIVERSAL TONIC}

Stevioside has a shielding influence on the degradation of vitamin $\mathrm{C}$ in comparison to other sweeteners (Stoyanova et al., 2011). Stevia rebaudiana is also approved as a nutritional increment or an herb but not as a sweetener by USFDA (Stancik \& Scholar, 2005). Proteins, phytochemicals, and minerals present in Stevia rebaudiana are crucial in the protection of good health. Leaf extract of Stevia rebaudiana is helpful as alcohol abuses, diuretic, digestive aid and as a food additive (Bharat et al., 2013).

\section{STEVIOL GLyCOSIDES VS. SUCROSE}

In comparison with other sweeteners, nutrient composition of Stevia rebaudiana leaves maintain its status as a low caloric sweetener of energy value in Stevia rebaudiana is $27 \mathrm{kcal}$ per 100gram which is less than others (Anonymous, 2000). Medical evidences show that excessive use of sugar (sucrose) obtained from sugarcane affects human health by the addition of calories (WHO; 2003). Sucrose, usually considered as high caloric, has a tendency to intensify fat deposition. Diseases associated with excessive use of sugar leads to several metabolic disorders like diabetes due to increase in liver glucose production and raises in blood level, blood cancer, cognitive decline and initiation of aging process due to damage of lipids, proteins and DNA (Lustig, 2010; Tappy, 2010).

Excessive use of sucrose exerts similar damage to liver like alcohol because alcohol is obtained from sugar fermentation (Lustig, 2010). In this context, Stevia rebaudiana is a totally natural herb with no calories and no adverse effects on the body. Savita et al. (2004a) stated that $1 \mathrm{gm}$ Stevia rebaudiana in $100 \mathrm{ml}$ of water is equal to $20 \mathrm{gm}$ of sucrose in $100 \mathrm{ml}$ water in term of sweetness. Apart from this, Steviol glycosides extracted from the leaves of Stevia rebaudiana are anti-carcinogenic, anti-cariogenic, anti-diabetic, anti-diarrheal, anti-inflammatory, antihypertensive, anti-microbial, anti-oxidant, diuretic, digestive aider, immune-regulator, vasodilator and alcohol abuse in nature (Jaitak et al., 2008; Lemus-Mondaca et al., 2012). Stevia rebaudiana also restrict the carving of sweets and help limiting calorie consumption in the diet (Savita et al., 2004a).

\section{STEVIOL GLYCOSIDES VS. OTHER NON-CALORIC SWEETNERS}

Mostly there are two types of non-caloric sweeteners i.e., natural and artificial sweeteners. Disadvantages of artificial sweeteners are much more than their advantages. Artificial sweeteners including aspartame, saccharin, glycyrrhizin and cyclamate are associated with phenylketonuria, blood cancer, bladder cancer, pseudo-aldosteronism and testicular atrophy along with dreadful cardiovascular effects respectively (Butchko et al., 2001; Pearson 2001; Bopp and Price, 2001, Yadav \& Guleria, 2012). Some other commercially used less or non-caloric sweetening compounds are e.g. glycyrrhizin, mogroside, phyllodulcin, thaumatin, xylitol, and stevioside (Kim \& Kinghorn, 2002; DuBois \& Prakash, 2012). Among all these artificial or natural sweeteners, Steviol glycosides, a group of diterpene glycoside, are the best choice as an alternative non-caloric sweeteners having about 10 different natural sweetening agents, which are about 150-300 times sweeter than sucrose (Table 5) with no effect on human health (Dacome et al., 2005). Although, Steviol glycosides are present in all plant organs but their concentration is high only in leaves of Stevia rebaudiana. Amount of Steviol glycosides present in the leaves of stevia is shown in Table. 6.

\section{ROLE IN FOOD INDUSTRY}

Use of sugar formulated dietary in routine life increases the rate of several complication like cancer, diabetes, enzymatic dysfunction, obesity, interferes in $\mathrm{Ca} 2+$ and $\mathrm{Mg} 2+$ absorption and cardiovascular diseases (Vartanian, 
2007; Gibson, 2008; Vasanti, 2010). Increased rate of such complications grabbed the attention of scientist \&researchers toward the development and domestication of new alternative food crops. Therefore, use of alternative less or non-caloric natural sweeteners can be a suitable replacement of sugar as a food ingredient. In this context, Stevia rebaudiana can be used as a substitute source of less or non-caloric natural sweetener. Leaves of Stevia rebaudiana is considered as a reliable basis of protein, carbohydrates and crude fibre (Braz de Oliviera et al., 2011). Nowadays, Stevia rebaudiana is becoming a major source of high potency natural sweetener used as substitute for saccharose in the production of low or less caloric natural food products and in future it can also be used as antidiabetic, anti-carcinogenic, anti-hypotension pharmaceutical product (Savita et al., 2004a; Midmore \& Rank, 2006; Pol, 2009; Goyal, 2010).

Steviol glycosides present in the leaves of Stevia rebaudiana are becoming famous with time and are available in market as an alternative food supplement in many industrial products e.g. confectionaries, coffee, fruit juices, ice creams, jams, sweets, soft drinks, porridge, tea and is also used as color enhancers (Goyal et al., 2010). Steviol glycosides, stevioside \& rebaudioside A are the primary ingredients used in food and the product containing higher concentration of rebaudioside A is usually referred as Rebiana (Carakostas et al., 2008). In most of the parts of world, steviol glycosides are replacing sucrose as a substitute food ingredient in numerous food industries like cereals, yoghurt, pickles, candy, soybeans and soya sauce, and seafood's (Wallin, 2007; Koyama et al., 2003; Amzad-Hossain et al., 2010; Goyal et al., 2010). In 2008, the WHO/FAO Expert Committee on Food Additives (JECFA) and US Food and Drug Administration (USFDA) declared the use of steviol glycosides in defined range of food and beverages industries (Contreras, 2013). In 2009, France approved the use of rebaudioside A as a natural sweetener (Yadav \& Guleria, 2012).In this context, European Commission in 2011 allowed the use of steviol glycosides as food supplement in order to establish maximum content for foods and beverages (Stoyanova et al., 2011).

One of the major problems associated with steviol glycosides is bitterness aftertaste. Michalik et al., 2010 found that alkaloid iminosugar, steviamine, is responsible for the bitter taste of steviol glycosides. Many food companies are wishing to use Steviol glycoside as a sweetener, but its bitter taste is creating hurdle for its wide spread use. Therefore,food companies are reluctant to explore the benefits of natural sweetness of Stevia rebaudiana. If the problem of bitter taste is overcomes then not a single natural or artificial sweetener will able to grab the sweetening status of Stevia rebaudiana.This may be achieved by cultivating this crop on different kinds of soils, by using different combinations of fertilizers and by using different molecular techniques which could affect its chemical properties to lessen its bitterness.

The suitability of a food can be described in different aspects by which it is cooked and handled (Savita et al., 2004a). Leaf powder ofStevia rebaudiana can be used as a sweetener in different food items. The bulk density of Stevia rebaudiana is lower as compare to other cereals and pulses which makes it an important factor for child feed products e.g. porridge, biscuits, cookies etc.

\section{Potential In Agriculture}

Leaves of Stevia rebaudiana possesses certain insecticidal property by showing resistant against aphids. For the researchers \& farmers, Stevia rebaudiana represents a new opportunity for research but still a lot of information about the optimum production technology is required for its successful establishment as a crop in Pakistan. Furthermore, it can be utilized as a source for the production of new metabolites in future (Hawke, 2003).

\section{SAFety ProfiLe}

Two major steviol glycoside, present in the leaves of Stevia rebaudianaare Rebaudioside A \& Stevioside, used as alternative natural sweeteners (Wheeler et al., 2008). Earlier, Filho et al. (1989) and Melis (1999) stated that both these steviol glycosides have negative effect on the reproductive ability in male by reducing testosterone levels and sperm count. But, recent studies on the reproductive and general toxicity of Rebaudioside A revealed that Stevia rebaudiana is safe even if intake at high level as a natural sweetener (Brunswick 2008; Williams \& Burdock, 2009; Qing, 2010). Investigations on these steviol glycosides showed that they also lack mutagenic, genotoxic prospective and are non-allergic and non-toxic (Geuns et al., 2004; Rajab et al., 2009). Patients suffering from diabetes intending to maintain their sugar level and from obesity aiming to lose their weight by escaping sucrose from their routine life can safely use stevioside as an alternative sugar without making their life tasteless. 
Studies revealed that if sucrose is replaced with such type of steviol glycosides like Rebaudioside A \& Stevioside in our routine life then it will help in eliminating the risk of diabetes, obesity, cardiovascular and other harmful diseases from Pakistan.

\section{CONCLUSION}

Stevia rebaudiana is a newly emerging alternative sugar crop in many regions of the globe. As compare to other natural and artificial sugars Stevia rebaudiana is highly nutritious, delicious, and low or non-caloric promising sugar crop. Leaves of Stevia rebaudiana contain higher concentration of steviol glycosides and are 150-300 times sweeter than sucrose with no dreadful effect on the human health. Apart from this, these steviol glycosides are anti-diabetic, anti-hypertensive, anti-oxidant, anti-microbial, anti-inflammatory, anti-carcinogenic, anti-cariogenic, anti-diarrheal, immune-regulator, vasodilator, diuretic, digestive aider, and alcohol abuse in nature. Moreover, these Steviol glycosides can be used as a skin tonic, tobacco carving, food supplement and food preservative. Keeping in view the importance of Stevia rebaudiana awareness should be created among sugar producers and consumers about the nutritional and pharmacological properties of Stevia rebaudiana as a natural alternative sweetener. Furthermore, to use Stevia rebaudiana as an alternative sugar crop which will aid in the development of new research project in term of production technology, steviol glycoside extraction and improvement in quality of steviol glycoside in Pakistan. The increasing mortality rate due to cancer, diabetes, obesity and cardiovascular diseases can be controlled to some extent by the use of these steviol glycosides. Therefore, we conclude Stevia rebaudiana as an ideal candidate as an alternative sugar crop in Pakistan and further researches should be planned on its cultivation and pharmaceutical uses.

Table1. Classification and Optimum Ecological Requirement for the Cultivation of Stevia rebaudiana(Adriana et al. 1996; Jayaraman et al., 2008; Madan et al., 2010)

\begin{tabular}{|c|c|c|c|}
\hline \multicolumn{2}{|c|}{ Classification } & \multicolumn{2}{c|}{ Requirements for Cultivation } \\
\hline Technical name & Stevia rebaudiana & Latitude & Between $22^{\circ} 24^{\circ}$ \\
\hline Genus & Stevia & Temperature & $15^{\circ} \mathrm{C}-35^{\circ} \mathrm{C}$ \\
\hline Family & Asteraceae/Compositae & Soil pH & $5.5-6.0$ (Slightlyacidic) \\
\hline Sub-family & Asteraceae & Soil Type & Sandy loam Loam \\
\hline Common Name & $\begin{array}{c}\text { Stevia, Sweet leaf, Sugar Leaf, Candy } \\
\text { Leaf, Sweet Honey Leaf, Rebiana. }\end{array}$ & Rainfall & $1200-1700 \mathrm{~mm}$ \\
\hline Synonyms & Eupatorium rebaudianum Bertoni & Climatic Zone & Semi TropicalTemperate \\
\hline No. of Chromosomes & $2 \mathrm{n}=22$ & & \\
\hline
\end{tabular}

Table2. Nutritional composition of Stevia rebaudiana reported by various authors

\begin{tabular}{|c|c|c|c|c|c|c|c|c|c|}
\hline $\begin{array}{c}\text { Nutrient } \\
\text { composition }\end{array}$ & $\begin{array}{c}\text { Savita } \\
\text { et al., } \\
2004 \mathrm{a}\end{array}$ & $\begin{array}{c}\text { Tadhani and } \\
\text { Subhash, } \\
2006\end{array}$ & $\begin{array}{c}\text { Goyal } \\
\text { et al., } \\
2010\end{array}$ & $\begin{array}{c}\text { Kaushik } \\
\text { et al., } \\
2010\end{array}$ & $\begin{array}{c}\text { Serio } \\
2010\end{array}$ & $\begin{array}{c}\text { Abou-Arab } \\
\text { et al., } \\
2010\end{array}$ & $\begin{array}{c}\text { Atteh } \\
\text { et al., } \\
2011\end{array}$ & $\begin{array}{c}\text { Yadav and } \\
\text { Guleria, } \\
2012\end{array}$ & $\begin{array}{c}\text { Gasmalla } \\
\text { et al., } \\
2014\end{array}$ \\
\hline $\begin{array}{c}\text { Moisture } \\
(\mathrm{g} / 100 \mathrm{~g})\end{array}$ & 7 & - & 4.65 & 7.7 & - & 5.37 & - & - & 10.73 \\
\hline $\begin{array}{c}\text { Energy } \\
(\mathrm{kcal} / 100 \mathrm{~g})\end{array}$ & 270 & - & - & - & - & - & - & - & - \\
\hline $\begin{array}{c}\text { Protein } \\
(\mathrm{g} / / 100 \mathrm{~g})\end{array}$ & 10 & 20.4 & 11.2 & 12 & 11.2 & 11.4 & 16 & $12-20.4$ & 13.68 \\
\hline Fat (g/100g) & 3 & 4.34 & 1.9 & 2.7 & 5.6 & 3.73 & 2.6 & $2.7-4.34$ & 6.13 \\
\hline $\begin{array}{c}\text { Carbohydrate } \\
(\mathrm{g} / 100 \mathrm{~g})\end{array}$ & 52 & 35.2 & - & - & 53 & 61.9 & - & 35.2 & 63.1 \\
\hline Ash (g/100g) & 11 & 13.1 & 6.3 & 8.4 & & 7.41 & 15.5 & 13.12 & 12.06 \\
\hline $\begin{array}{c}\text { Crude fiber } \\
(\mathrm{g} / 100 \mathrm{~g})\end{array}$ & 18 & - & 15.2 & - & 15 & 15.5 & 6.8 & - & 5.03 \\
\hline $\begin{array}{c}\text { Calcium } \\
(\mathrm{mg} / / 100 \mathrm{~g})\end{array}$ & 464.4 & 1550 & 544 & 722 & 600 & 17.7 & 8.2 & - & - \\
\hline $\begin{array}{c}\text { Phosphorus } \\
(\mathrm{mg} / 100 \mathrm{~g})\end{array}$ & 11.4 & 350 & 318 & & 318 & - & 2.6 & - & - \\
\hline $\begin{array}{c}\text { Potassium } \\
(\mathrm{mg} / 100 \mathrm{~g})\end{array}$ & 1800 & 2510 & 1780 & 839 & 1800 & 21.15 & 17.3 & - & - \\
\hline Iron (mg//100g) & 55.3 & 36.3 & 3.9 & 31.1 & 3.9 & 5.89 & 366 & - & - \\
\hline
\end{tabular}


American Research Journal of Agriculture, Volume 1, Issue 1, February 2015

ISSN 2378-9018

\begin{tabular}{|l|c|c|c|c|c|c|c|c|c|}
\hline $\begin{array}{l}\text { Sodium } \\
(\mathrm{mg} / 10 \mathrm{~g})\end{array}$ & 190.0 & 160 & 89.2 & 32.7 & - & 14.93 & 0.7 & - & - \\
\hline $\begin{array}{l}\text { Magnesium } \\
(\mathrm{mg} / 100 \mathrm{~g})\end{array}$ & - & - & 349 & - & 500 & 3.26 & 2.4 & - & - \\
\hline Zinc (mg/100g) & - & 6.39 & 1.5 & - & - & 1.26 & 20 & - & - \\
\hline
\end{tabular}

Table3. Concentration of Amino Acids in Leaf Extract of Stevia rebaudiana(Li et al., 2011)

\begin{tabular}{|l|c|c|}
\hline Kind of Amino acids & Name of amino acids & Percentage (\%) \\
\hline \multirow{4}{*}{ Essential amino acids } & Arginine & 0.796 \\
\cline { 2 - 3 } & Histidine & 0.337 \\
\cline { 2 - 3 } & Isoleucine & 0.716 \\
\cline { 2 - 3 } & Leucine & 1.288 \\
\cline { 2 - 3 } & Lysine & 1.050 \\
\cline { 2 - 3 } & Phenylalanine & 0.867 \\
\cline { 2 - 3 } & Proline & 1.671 \\
\cline { 2 - 3 } & Threonine & 0.744 \\
\cline { 2 - 3 } & Valine & 0.935 \\
\cline { 2 - 3 } & Alanine & 0.941 \\
\cline { 2 - 3 } & Asparagine & 1.658 \\
\cline { 2 - 3 } & Glutamine & 1.894 \\
\cline { 2 - 3 } & Glycine & 0.846 \\
\cline { 2 - 3 } & Serine & 1.036 \\
\cline { 2 - 3 } & Tyrosine & 0.485 \\
\cline { 2 - 3 }
\end{tabular}

Table4. Chemical composition of the essential oils (Siddique et al., 2012) and Functional properties of leaf powder of Stevia rebaudiana(Savita et al., 2004a)

\begin{tabular}{|c|c|c|c|}
\hline \multicolumn{2}{|c|}{ Fhemical Composition of Essential Oils } & \multicolumn{2}{c|}{ Punctional properties } \\
\hline Essential Oil & $\mathbf{( \% )}$ & Bulk density & $0.443 \mathrm{~g} / \mathrm{ml}$ \\
\hline Cyclopentasiloxane & 0.88 & Water absorption capacity & $4.7 \mathrm{ml} / \mathrm{g}$ \\
\hline Geranyl vinyl ether & 0.14 & Fat absorption capacity & $4.5 \mathrm{ml} / \mathrm{g}$ \\
\hline Cyclohexasiloxane & 4.4 & Emulsification value & $5 \mathrm{ml} / \mathrm{g}$ \\
\hline Indole & 0.17 & Swelling & $5.01 \mathrm{ml} / \mathrm{g}$ \\
\hline Caryophyllene & 0.08 & Solubility & $0.365 \mathrm{ml} / \mathrm{g}$ \\
\hline (-)-Spathulenol & 2.21 & $\mathrm{pH}$ & 5.95 \\
\hline Caryophyllene oxide & 1.23 & & \\
\hline Santalol, cis alpha pyranomenthol & 0.07 & & \\
\hline Ledene oxide-(II) & 0.32 & & \\
\hline$\alpha$-Cadinol & 0.21 & & \\
\hline Aristolene epoxide & 2.98 & & \\
\hline Silanediol & 0.18 & & \\
\hline
\end{tabular}

Table5. Sweetening strength of Steviol glycosides as compare to sucrose (Puri et al., 2011)

\begin{tabular}{|l|c|c|c|c|c|c|c|c|c|c|}
\hline \multicolumn{1}{|c|}{$\begin{array}{c}\text { Stevioside } \\
\text { Glycosides }\end{array}$} & $\begin{array}{c}\text { Kinghorn } \\
\text { and } \\
\text { Soejarto, } \\
\mathbf{1 9 8 5}\end{array}$ & $\begin{array}{c}\text { Crammer } \\
\text { and Ikan, } \\
\mathbf{1 9 8 7}\end{array}$ & $\begin{array}{c}\text { Kolb } \\
\text { et al., } \\
\mathbf{2 0 0 1}\end{array}$ & $\begin{array}{c}\mathbf{G e u n s} \\
\mathbf{2 0 0 3}\end{array}$ & $\begin{array}{c}\text { Pol } \text { et } \\
\text { al., } \\
\mathbf{2 0 0 7}\end{array}$ & $\begin{array}{c}\text { Gardana } \\
\text { et al., } \\
\mathbf{2 0 1 0}\end{array}$ & $\begin{array}{c}\text { Goya } \\
\text { l } \text { et } \\
\text { al., }\end{array}$ & $\begin{array}{c}\text { Atte } \\
\mathbf{h} \text { et } \\
\text { al., } \\
\mathbf{2 0 1 1}\end{array}$ & $\begin{array}{c}\text { Jawor } \\
\text { ska } \\
\text { et al., } \\
\mathbf{2 0 1 2}\end{array}$ & $\begin{array}{c}\text { Yadav } \\
\text { and } \\
\text { Guleria, } \\
\mathbf{2 0 1 2}\end{array}$ \\
\hline $\begin{array}{l}\text { Stevioside } \\
\text { (g/100g) }\end{array}$ & $5-10$ & $3-10$ & $\begin{array}{c}3.78- \\
9.75\end{array}$ & $4-13$ & $\begin{array}{c}43.1- \\
79.6\end{array}$ & 5.8 & 9.1 & 6.5 & 2.0 & $4-14$ \\
\hline $\begin{array}{l}\text { Steviol } \\
\text { (g/100g) }\end{array}$ & - & - & - & - & - & - & - & - & 0.70 & - \\
\hline $\begin{array}{l}\text { Steviol } \\
\text { bioside } \\
\text { (g/100g) }\end{array}$ & - & - & - & Trace & $0.3-3$ & - & - & - & 1.2 & $>0.4$ \\
\hline $\begin{array}{l}\text { Rebaudioside- } \\
\text { A (g/100g) }\end{array}$ & $2-4$ & 1.0 & $1.62-$ & $2-4$ & $7.6-$ & 1.8 & 3.8 & 2.3 & 5.0 & $2-4$ \\
\hline
\end{tabular}


American Research Journal of Agriculture, Volume 1, Issue 1, February 2015 ISSN 2378-9018

\begin{tabular}{|l|c|c|c|c|c|c|c|c|c|c|}
\hline $\begin{array}{l}\text { Rebaudioside- } \\
\text { B (g/100g) }\end{array}$ & - & - & - & Trace & 0.02 & - & - & - & 0.50 & - \\
\hline $\begin{array}{l}\text { Rebaudioside- } \\
\text { C (g/100g) }\end{array}$ & $1-2$ & - & - & $1-2$ & $0.5-6$ & 1.3 & 0.6 & - & 2.0 & $1-2$ \\
\hline $\begin{array}{l}\text { Rebaudioside- } \\
\text { D (g/100g) }\end{array}$ & - & - & - & Trace & 0.4 & - & - & - & 3.3 & $>0.4$ \\
\hline $\begin{array}{l}\text { Dulcoside-A } \\
(\mathrm{g} / 100 \mathrm{~g})\end{array}$ & $0.4-0.7$ & 0.2 & - & $\begin{array}{c}0.4- \\
0.7\end{array}$ & $\begin{array}{c}0.2- \\
0.4\end{array}$ & - & 0.3 & - & 1.0 & $0.4-0.7$ \\
\hline
\end{tabular}

Table6. Amount of sweet glycosides in Stevia rebaudiana leaves reported by various authors

\begin{tabular}{|c|c|}
\hline Steviol glycosides & Sweetening Strength \\
\hline Stevioside & $150-300$ \\
\hline Rebaudioside-A & $350-450$ \\
\hline Rebaudioside-B & $300-350$ \\
\hline Rebaudioside-C & $50-120$ \\
\hline Rebaudioside-D & $200-300$ \\
\hline Rebaudioside-E & $250-300$ \\
\hline Rebaudioside-F & ND \\
\hline Steviol bioside & $100-125$ \\
\hline Dulcoside-A & $50-120$ \\
\hline
\end{tabular}

\section{REFERENCES}

[1] Abou-Arab, A.E., A.A. Abou-Arab and M.F. Abu-Salem, 2010. Physico-chemical Assessment of Natural Sweeteners Steviosides Produced from Stevia Rebaudiana Bertoni Plant. African J. Food Sci. 4(5): 269- 281.

[2] Abu-Elteen K., 2005. The Influence of Dietary Carbohydrates On In Vitro Adherence Of Four Candida Species To Human Buccal Epithelial Cells. Micro. Eco. Health \& Disease 17: 156-162.

[3] ADA., 2010. American Diabetes Association.Diagnosis and classification of diabetes mellitus. Diab. care 33(1): 62-69.

[4] Adriana, P.F., P.M. Rous, M.A. Marin-Morales, C.F. Raus and J.N. Nakajima, 1996. Chromosomes Studies In Some Stevia cav. (Compositae) Species From Southern Brazil. Brazilian J. Gen. 19(4): 605-609.

[5] Ahmad, N., H. Fazal, B. Abbasi and S. Farooq, 2010. Efficient Free Radical Scavenging Activity Of Ginkgo Biloba, Stevia Rebaudiana And Parthenium hysterophorus Leaves Through DPPH (2, 2-diphenyl-1-picrylhydrazyl. Int. J. Phytomed. 2(3): 231-239.

[6] Akram, M., A. Shahid and A. Sattar, 2013. Stevia. Department of Plant Physiology \& Department of Extension, Ayub Agricultural Research Institute, Faisalabad (Pakistan). 4 p

[7] Amzad-Hossain, M., A. Siddique, S. Mizanur-Rahman and M. A. Hossain, 2010.Chemical Composition Of The Essential Oils Of Stevia Rebaudiana Bertoni Leaves. Asian J. Trad. Med. 5(2): 56-61.

[8] Anbajhagan, M., M. Kalpana, R. Rajendran, V. Natarajan and D. Dhanavel, 2010. In-vitro Production of Stevia Rebaudiana Bert. Emirates J. Food \& Agri. 22: 216-222

[9] Anonymous. (2000. Low - Calorie Sweeteners And Health. IFIC Review. Washington. 12 p.

[10] Anton, S.D., C.K. Martin, H. Han, S. Coulon, W.T. Cefalu, P. Geiselman and D.A. Williamson, 2010. Effect of stevia, aspartame and sucrose on food intake, satiety and postprandial glucose and insulin levels. Appe. 55(1): 37-43.

[11] Apel, K. and H. Hirt, 2004. Reactive oxygen species: metabolism, oxidative stress, and signal transduction. Ann. Rev. Plant Bio.55: 373-399.

[12] Arya, A., S. Kumar and M. Kasana, 2012.Anti-inflammatory Activity of In-Vitro Regenerated Calli and In-Vivo Plant of Stevia Rebaudiana Bertoni. Int. J. Sci. \& Res. 2(8): 435-439.

[13] Atteh, J., O. Onagbesan, K. Tona, J. Buyse, E. Decuypere and J. Geuns, 2011. Potential Use Of Stevia Rebaudiana In Animal Feeds. Arch. de Zoo. 60(229): 133-136.

[14] Bairagi, S.M., A.A. Aher, N. Nema and P.K. Nimase, 2012. Anti-Inflammatory Evaluation Of Methanol Extract And Aqueous Fraction Of The Bark Of Bauhinia Variegata (Leguminosae). Int. J. Res. Pharm. \& Chem. 2: 77-87.

[15] Barathi N., 2003. Stevia-The calorie free natural sweetener. Nat. Prod. Rad. 2: 120-122.

[16] Belda-Galbis, C.M., M.C. Pina-Pérez, J. Espinosa, A. Marco-Celdrán, A. Martínez and D. Rodrigo, 2014. Use of the modified Gompertz equation to assess the Stevia Rebaudiana Bertoni antilisterial kinetics. Food Microbiol. 38: 56-61. 
[17] Bharat, P., V. Yadav, A. Kainth, L. Sharma and B. Thomas, 2013. Stevia (Meethi patti): Prospects As An Emerging Natural Sweetener. Int. J. Pharm. \& Chem. Sci. 2 (1):214-225

[18] Bhimba, B.V., J. Meenupriya, E.L. Joel, DE Naveena, S. Kumar and M Thangaraj, 2010. Antibacterial activity and characterization of secondary metabolites isolated from mangrove plant Avicennia officinalis. Asian Pac. J. Trop. Med. 3(7): 544-546.

[19] Bolaños, J. and J. Ramírez, 2007. Efectos del extracto de Stevia Rebaudiana bertoni en la enfermedad periodontal. En: XXIII congreso científico odontológico ACCO; en:http://congresoacco.com/articulos/articulos/2007/9Efectos_de_Stevia_rebaudiana_bertoni_en_enfermedad_peridontal.p df

[20] Bondarev, N., O. Reshetnyak and A. Nosov, 2003. Effects of nutrient medium composition on development of Stevia Rebaudiana shoots cultivated in the roller bioreactor and their production of steviol glycosides, Plant Sci. 165: 845-850.

[21] Bondarev, N.I., 1998. Effects of exogenous growth regulators on callusogenesis and growth of cultured cells of Stevia Rebaudiana Bertoni.Russian J. Plant Physio. 45(6): 770-774.

[22] Boonkaewwan, C., C. Toskulkao and M. Vongsakul, 2006. Anti-inflammatory and immunomodulatory activities of stevioside and its metabolite steviol on THP-1 cells. J. Agri. Food Chem. 54(3): 785-789.

[23] Bopp, B.A. and P. Price, 2001. Cyclamate. In: O'Brien NL (ed). Alternative Sweeteners: Third Edition, Revised and Expanded. Marcel Dekker, New York: pp: 63-85.

[24] Boue, S.M., T.E. Cleveland, C. Carter-Wientjes, B.Y. Shih, D. Bhatnagar, J.M. Mclachlan and M.E. Burow, 2009. Phytoalexin-enriched functional foods. J. Agri. Food Chem. 57: 2614-2622.

[25] Brahmachari, G., L. Mandal, R. Roy, S. Mondal and A. Brahmachari, 2011. Stevioside and related compounds-molecules of pharmaceutical promise: a critical overview. Archiv. der Pharm. 344(1): 5-19.

[26] Brambilla, E., M. G. Cagetti, A, Ionescu, G, Campus and P. Lingström, 2014. An in vitro and in vivo Comparison of the Effect of Stevia rebaudiana Extracts on Different Caries-Related Variables: A Randomized Controlled Trial Pilot Study. Caries Res. 48: 19-23

[27] Brandle, J.E., A.N. Starratt and M. Gijzen, 1998. Stevia rebaudiana: its agricultural, biological and chemical properties, Can. J. Plant Sci. 78 (4): 527-536.

[28] Brandle, J.E. and P.G. Telmer, 2007. Steviol glycoside biosynthesis. Phytochem. 68: 1855-1863.

[29] Braz de Oliviera, A., R.A.C. Goncalves, T.P.C. Chirrito, M.M.D. Santos, L.M. deSouza, P.A.J. Gorin, G.L. Sassakib and M. Lacomini, 2011. Structure and degree of polymerization of fructool igodaccharides persent in roots and leaves of Stevia Rebaudiana (Bert) Bertoni. Food Chem. 129: 305-311.

[30] Brunswick D.J., 2008.A critical review of the genetic toxicity of steviol and steviol glycosides. Food Chem. Toxicol. 46 (7): 583-591.

[31] Butchko, H.H., W.W. Stargel, C.P. Comer, D.A. Mayhew and S.E. Andress, 2001. Aspartame. In: O’Brrien NL (ed). Alternative Sweeteners: Third Edition revised and expanded. Marcel Dekker, New York: pp: 41-61.

[32] Carakostas, M.C., I. Prakash, A.D. Kinghorn, C.D. Wu and D.D. Soejarto, 2011. Steviol Glycosides. CRC Press (Taylor and Francis): Boca Raton, Florida, 159-180.

[33] Carneiro, J.W.P., A.S. Muniz and T.A. Guedes, 1997. Greenhouse bedding plant production of Stevia Rebaudiana (Bert) bertoni. Can. J. Plant Sci. 77: 473-474.

[34] Chalapathi, M.V. and B. Shivraj, 1997. Nutrient uptake and yield of Stevia (Stevia Rebaudiana bertoni) as influenced by methods of planting and fertilizers levels. Crop Res. 14: 205-208.

[35] Chalapathi, M.V., 1999. Vegetative Propagation of Stevia. Crop Res. 18: 2

[36] Chang, L., Z. Wang and D. Yang, 2007. Research Summary of Method for Chemical Analysis for Steviosides. Foreign Medical Sciences, Section Hygiene, 197-200.

[37] Chatsudthipong, V. and C. Muanprasat, 2009. Stevioside and related compounds: Th erapeutic benefi ts beyond sweetness. Pharmacol. \& Therap. 121(1): 41-54

[38] Chaturvedula, V.S.P., M. Upreti and I Prakash, 2011.Diterpene glycosides from Stevia Rebaudiana. Molecules 16(5): 3552-3562.

[39] Chen, T.H., S.C. Chen, P. Chan, Y.L. Chu, H.Y. Yang and J.T. Cheng, 2005. Mechanism of the hypoglycemic effect of stevioside, a glycoside of Stevia Rebaudiana. Planta Med. 71(2): 108-113.

[40] Chu, Y., C. Chang and H. Hsu, 2000. Flavonoid content of several vegetables and their antioxidant activity. J. Sci. Food \& Agri. 80(5): 561-566.

[41] Contreras, M.S., 2013. Anticariogenic properties and effects on periodontal structures of Stevia Rebaudiana Bertoni. Narrative review. J. Oral Res. 2(3): 158-166.

[42] Crammer, B. and R. Ikan, 1986.Sweet glycosides from the Stevia plant. Chem. Br. 22: 915-916. 
[43] Crammer, B. and R. Ikan, 1987.Progress in the chemistry and properties of the rebaudiosides. In: Grenby TH (ed). Developments in Sweeteners. London: Elsevier Applied Science, 45-64.

[44] Dabur, R., M. Ali, H. Singh, J. Gupta and G. Sharma, 2004. A novel antifungal pyrrole derivative from Datura metel leaves. Pharmazie 59: 568-570.

[45] Dacome, A.S., C.D.S. Cleuza, E.M.D. Cecila, D.F. Jose, A. Juliana and C.D.C. Silvio, 2005. Sweet diterpenic glycosides balance of a new cultivar of Stevia Rebaudiana electrophoretic methods. Process Biochem. 40: 3587-3594.

[46] Darabpour, E., H. Motamedi and S.M.S. Nejad, 2010. Antimicrobial properties of Teucrium polium against some clinical pathogens. Asian Pac. J. Trop. Med. 3(2): 124-127.

[47] Debnath M., 2008. Clonal propagation and antimicrobial activity of an endemic medicinal plant Stevia Rebaudiana. J. Med. Plants Res. 2(2): 045-051.

[48] Dey, A., S. Kundu, A. Bandyopadhyay and A. Bhattacharjee, 2013a. Efficient micropropagation and chlorocholine chloride induced stevioside Production of Stevia Rebaudiana Bertoni, C. R. Biologies 336: 17-28.

[49] Dey, A., S. Paul, S. Kundu, A. Bandyopadhyay and A. Bhattacharjee, 2013b. Elevated antioxidant potential of chlorocholine chloride-treated in vitro grown Stevia rebaudiana Bertoni. Acta Physiol. Planta. 35(6): 1775-1783.

[50] DuBois, G.E. and I. Prakash, 2012. Non-caloric sweeteners, sweetness modulators, and sweetener enhancers. Ann. Rev. Food Sci. \& Tech. 3: 353-380.

[51] Durán, A., M. Rodríguez, A. Cordón and C. Record, 2012. Estevia (Stevia Rebaudiana), edulcorante natural y no calórico. Rev. Chil. Nutr. 39(4): 203-206.

[52] Dwivedi, R.S., 1999. Unnurtured and untapped sweet non- sacchariferous plant species in India. Current Sci. 76: 14541461.

[53] Dyrskog, S.E., P.B. Jeppensen, M. Colombo, R. Abudula and K. Hermansen, 2005. Preventive effects of soy based diet supplemented with stevioside on development of type 2 diabetes. Metabolism 54:1181-1188.

[54] Edeoga, H., D. Okwu and B. Mbaebie, 2005. Phytochemical constituents of some Nigerian medicinal plants. African J. Biotech. 4(7): 685-688.

[55] Fazal, H., N. Ahamad and M.A. Khan, 2011. Physicochemical, phytochemical evaluation and DPPH-scavenging antioxidant potential in medicinal plants used for herbal formulation in Pakistan. Pak J Bot 43: 63-67.

[56] Ferri, L.A., W. Alves-Do-Prado, S.S. Yamada, S. Gazola, M.R. Batisla and R.B. Bazotte, 2006. Investigation of the antihypertensive effect of oral crude stevioside in patients with mild essential hypertension. Phytother. Res. 20(9):732-736.

[57] Filho, R.M.O., O.A. Uehara, C.A.S.A. Minetti and L.B.S. Valle, 1989. Chronic administration of aqueous extract of Stevia Rebaudiana Bertoni in rats: Endocrine effects. Gen. Pharmacol.: Vascu. Sys. 20:187-191.

[58] Frederico, A.P., P.M. Ruas, M.A. Marin-Morales, C.F. Ruas and J.N. Nakajima, 1996. Chromosome studies in some Stevia. Cav. (Compositae) species from Southern Brazil. Brazilian J. Gen. 19(4):605-609.

[59] FSANZ (Food Standards Australia New Zealand), 2008. Steviol Glycosides as Intense Sweeteners - Final assessment report. Canberra.

[60] Galvez, M., C. Martin-Cordero, P.J. Houghton and M.J. Ayuso, 2005. Antioxidant activity of methanol extracts obtained from Plantago species. J. Agric. Food Chem. 53: 1927-1933.

[61] Garcia, D., J. Leiro, R. Delgado, M.L. Sanmartin and F.M. Ubeira, 2003. Mangifera indica L. extract (Vimang) and mangiferin modulate mouse humoral immune responses. Phytother. Res. 17(10): 1182-1187.

[62] Gardana, C., M. Scaglianti and P. Simonetti, 2010. Evaluation of steviol and its glycosides in Stevia Rebaudiana leaves and commercial sweetener by ultra high performance liquid chromatography-mass spectrometry. J. Chromatogr. A 1217:1463-1470.

[63] Gasmalla, M.A.A., R. Yang, A. Musa, X. Hua and W. Zhang, 2014. Physico-chemical Assessment and Rebauidioside A. Productively of Natural Sweeteners (Stevia Rebaudiana Bertoni). J. Food \& Nutr. Res. 2(5):209-214.

[64] Geeraert, B., F. Crombe, M. Hulsmans, N. Benhabiles, J. Geuns and P. Holvoet, 2010. Stevioside inhibits atherosclerosis by improving insulin signaling and antioxidant defense inobese insulin-resistant mice. Int. J. Obes. 34:569-577.

[65] Geuns, J., (2003. Stevioside. Phytochem.64(5): 913-921.

[66] Geuns, J.M., J. Buyse, A. Vankeirsbilck and L. Temme, 2004. About the safety of stevioside used as a sweetener. In: Leuven KU, Heverlee-Leuven (eds). Proceedings of the first symposium on the safety of stevioside, Belgium: 85-127.

[67] Ghanta, S., A. Banerjee, A. Poddar and S. Chattopadhyay, 2007. Oxidative DNA damage Preventive activity and antioxidant potential of Stevia Rebaudiana( Bertoni) Bertoni, A natural sweetner. J. Agric. Food Chem. 55(26):1096210967

[68] Gibson, S., 2008. Sugar-sweetned soft drink and obesity: A systematic review of the evidence from observation al studies and invention, Nutr. Res. 21(2):134-147.

[69] Goldberg, I., 1994. Functional Foods, Designer Foods, Pharmafoods, Nutraceuticals. Aspen Publishers, Chapman and Hall, New York. 
[70] Goyal, S., Samsher and R. Goyal, 2010. Stevia (Stevia Rebaudiana) a biosweetener: A review. Int. J. Food Sci. \& Nutr. 61 (1): $1-10$.

[71] Gregersen, S., P.B. Jeppesen, J.J. Holst and K. Hermansen, 2004. Antihyperglycemic effects of stevioside in type 2 diabetic subjects. Metabo. 53:73-6.

[72] Guariguata, L., D.R. Whiting, I. Hambleton, J. Beagley, U. Linnenkamp and JE Shaw, 2014. Global estimates of diabetes prevalence for 2013 and projections for 2035. Diab. Res. \& Clin. Prac. 103(2): 137-149.

[73] Guleria, P. and S.K. Yadav, 2013. Insights into steviol glycoside biosynthesis pathway enzymes through Structural Homology Modeling. Am. J. Biochem. Mol. Biol. 3: 1-19.

[74] Gupta, E., S. Purwar, S. Sundaram and G.K. Rai, 2013. Nutritional and therapeutic values of Stevia rebaudiana: A review. J. Med. Plants Res. 7(46): 3343-3353.

[75] Hawke, J., 2003. The Bittersweet Story of the Stevia Herb. In: Dorman T (ed), Facts, Fictions and Frauds in Modern medicine. Dorman Publishing, Washington. 8(3): 1-7

[76] Hossain, M.A., M.D. Shah, S.V. Sang, and M. Sakari, 2012. Chemical compositionand antibacterial properties of the essential oils and crude extracts of Merremia borneensis. J. King Saud Univ. Sci. 24: 243-249.

[77] Hou, W.C., R.D. Lin, K.T. Cheng, Y.T. Hung, C.H. Cho, C.H. Chen, S.Y. Hwang and M.H. Lee, 2003. Free radical scavenging activity of Taiwanese native plants, Phytomed. 10: 170-175.

[78] Huxley A., 1992. The New RHS Dictionary of Gardening. Royal Horticultural Society. MacMillan Press, London. 3000 p.

[79] Jagatheeswari, D. and P. Ranganathan, 2012. Studies on micropropagation of Stevia Rebaudiana Bert.. Inter. J. Pharm. Biol. Arch. 3: 315-320.

[80] Jahan, I.A., M. Mostafa, H. Hossain, I. Nimmi, A. Sattar, A. Alim and S.M.I. Moeiz, 2010. Antioxidant activity of Stevia Rebaudiana Bert.leaves from Bangladesh. Bangladesh Pharm. J. 13: 67-75.

[81] Jain, A., S. Sharma, M. Goyal, S. Dubey, S. Jain, J. Sahu, A. Sharma and A. Kaushik, 2011. Anti-inflammatory activity of Syzygium cumini leaves. Int. J. Phytomed. 2: 14-126

[82] Jaitak, V., A.P. Gupta, V.K. Kaul and P.S. Ahuja, 2008. Validated high-performance thin-layer chromatography method for steviol glycosides in (Stevia rebaudiana). J. Pharm. \& Biomed. Anal. 47(4): 790-794.

[83] Jaworska, K., A.J. Krynitsky and J.I. Rader, 2012. Simultaneous analysis of steviol and steviol glycosides by liquid chromatography with ultraviolet detection on a mixed-mode column: application to Stevia plant material and Steviacontaining dietary supplements. J. AOAC Int. 95(6): 1588-1596.

[84] Jayaraman, S., M.S. Manoharan and S. Illanchezian, 2008. In-vitro antimicrobial and antitumor activities of Stevia Rebaudiana (Asteraceae) leaf Extracts. Trop. J. Pharm. Res. 7: 1143-1149.

[85] Jeppesen, P.B., S. Gregersen, K.K. Alstrup and K. Hermansen, 2002. Stevioside induces antihyperglycaemic, insulinotropic and glucagonostatic effects in vivo: Studies in the diabetic Goto-Kakizaki (GK) rats. Phytomed. 9(1): 9-14.

[86] Jeppesen, P.B., S. Gregersen, S.E.D. Rolfsen, M. Jepsen, M. Colombo, A. Agger, J. Xiao and K. Hermansen, 2003. Antihyperglycemic and blood pressure-reducing effects of stevioside in the diabetic goto-kakizaki rat. Metabol. 52:372378.

[87] Jeppesen, P.B., S. Gregerson, C.R. Poulsen and K. Hermansen, 2000. Stevioside acts directly on pancreatic $\beta$ cells to secrete insulin: Actions independent of cyclic adenosine monophosphate and adenosine triphosphate-Sensitive $\mathrm{K}+$ channel activity. Metabol. 49(2): 208-214

[88] Karim, M.A., R. Jannat, M.S. Rahman and M.S. Haque, 2013. Micropropagation of stevia plant from nodal segments. Prog. Agri. 19(2): 21-26.

[89] Katayama, O., T. Sumida, H. Hayashi and H. Mitsuhashi, 1976.The Practical Application of Stevia and Research and Development Data. ISU Company, Japan. 747 p.

[90] Kaushik, R., N. Pradeep, V. Vamshi, M. Geetha and A. Usha, 2010. Nutrient composition of cultivated Stevia leaves and the influence of polyphenols and plant pigments on sensory and antioxidant properties of leaf extracts. J. Food Sci. Technol. 47: 27-33.

[91] Kelly, T., W. Yang, C.S. Chen, K. Reynolds and J. He, 2008.Global burden of obesity in 2005 and projections to 2030. Int. J. Obes. 32(9): 1431-1437.

[92] Kim, I., M. Yang, O. Lee and S. Kang, 2011. The antioxidant activity and the bioactive compound content of Stevia Rebaudiana water extracts. LWT - Food Sci. Technol. 44: 1328-1332.

[93] Kim, J., Y.H. Choi and Y.H. Choi, 2002. Use of stevioside and cultivation of Stevia Rebaudiana in Korea. In: Kinghorn AD (ed.), Stevia, the Genus Stevia. Medicinal and Aromatic Plants-Industrial Profiles, Vol. 19. London and NY: Taylor and Francis, 196-202.

[94] Kim, N.C., and A.D. Kinghorn, 2002. Sweet-tasting and sweetness-modifying constituents of plants. Nat. Prod. Chem. 27: 3-57. 
[95] Kinghorn, A. and D Soejarto, 1985. Current status of stevioside as a sweetening agent for human use, In: Wagner H, Hikino H, Farnsworth N, (eds), Economic and medicinal plant Research. Academic Press, London: pp: 1-52.

[96] Kinghorn, A.D., 2002. Overview. In: Kinghorn AD (ed), Stevia: The Genus Stevia. : Taylor and Francis, London: pp: 117.

[97] Kolb, N., J.L. Herrera, D.J. Ferreyra and R.F. Uliana, 2001. Analysis of sweet diterpene glycosides from Stevia Rebaudiana: improved HPLC method. J. Agric. Food Chem. 49: 4538-4541.

[98] Komissarenko, N.F., A.I. Derkach, I.P. Kovalyov and N.P. Bublik, 1994. Diterpene glycosides and phenylpropanoids of Stevia Rebaudiana Bertoni. Rastitel'Nye Resursy 1: 53-64.

[99] Koyama, E., K. Kitazawa, Y. Ohori, O. Izawa, K, Kakegawa and A. Fujino, 2003. In vitro metabolism of the glycosidic sweeteners, Stevia mixture and enzymatically modified Stevia in human intestinal microflora. Food Chem. Toxicol. 41: 359-374.

[100] Kumari, M. and S. Chandra, 2013. Localisation and Isolation of Fungal Endophytes from Healthy Tissue of Stevia rebaudiana (Bert.). Int. J. Phytomed. 5(4): 435-440.

[101] Leahy, J.L., 2005. Pathogenesis of type 2 diabetes mellitus. Arch. Med. Res. 36(3): 197-209.

[102] LeCroy, J.M., 2014. Factors Affecting Seed and Stem Cutting Propagation of Stevia rebaudiana (BERT.) Ph.D Thesis (Unpublished). Mississippi State Uni. Oktibbeha, Mississippi, United States.

[103] Lee, C.N., K, Wong, J. Liu, Y. Chen, J. Chen and P. Chan, 2001. Inhibitory effect of stevioside on calcium influx to produce anti-hypertension. Planta Med. 67:796-799.

[104] Lemus-Mondaca, R., A. Vega-Gálvez, L. Zura-Bravo and K. Ah-Hen, 2012.Stevia Rebaudiana Bertoni, source of a highpotency natural sweetener: A comprehensive review on the biochemical, nutritional and functional aspects. Food Chem. 132(1): 1121-1131

[105] Lewis, W.H., 1992. Early uses of Stevia Rebaudiana (Asteraceae) leaves as a sweetener in Paraguay. Econ. Bot. 46: 336337.

[106] Li, G., Wang, R., A.J. Quampah, Z Rong, C Shi, J Wu, 2011. Calibration and prediction of amino acids in stevia leaf powder using near infrared reflectance spectroscopy. J. Agri. Food Chem. 59(24): 13065-13071.

[107] Liu, J., P. Kao, P. Chan, Y. Hsu, C. Hou, G. Lien and J Cheng, 2002. Mechanism of the antihypertensive effect of stevioside in anesthetized dogs. Pharmacol. 67(1): 14-20.

[108] Lustig, R. H., 2010. The bitter truth about sugar. J. Am. Diet. Assoc. 110: 1307-1321.

[109] Madan, S., S. Ahmad, G.N. Singh, K. Kohli, Y. Kumar, R. Singh and M. Garg, 2010. Stevia Rebaudiana (Bert.) Bertoni e a review. Indian J. Nat. Prod. Resour. 1: 267-286.

[110] Maki, K.C., L.L. Curry, M.C. Carakostas, S. M. Tarka, M.S. Reeves, M.V. Farmer, J.M. McKenney and J.D. Bisognano, 2008. The hemodynamic effects of rebaudioside A in healthy adults with normal and low normal blood pressure. Food Chem. Toxicol. 46(7): 540-546.

[111] Melis, M., S. Rocha and A. Augusto, 2009. Steviol effect, a glycoside of Stevia Rebaudiana, on glucose clearances in rats. Braz. J. Biol. 69: 371-374.

[112] Melis, M.S., 1999. Effects of chronic administration of Stevia Rebaudiana on fertility in rats. J. Ethnopharmacol. 67(2): $157-161$

[113] Michalik, A., J. Hollinshead, L. Jones, G.W. Fleet, C.Y. Yu, X.G. Hu and R.J. Nash, 2010. Steviamine, a new indolizidine alkaloid from (Stevia Rebaudiana). Phytochem. 3(3): 136-138.

[114] Midmore, D.J. and A.H. Rank, 2002. A new rural industry - stevia - to replace important chemical sweeteners. Report for the Rural Industries, Research and Development Corporation Boston, Massachusetts (USA). 13 p.

[115] Midmore, J.D. and A.H. Rank, 2006. An intense natural sweetener-laying the ground work for a new rural industry. RIRDC Pub. 6: 20.

[116] Mishra, P., R. Singh, U. Kumar and V. Prakash, 2010. Stevia Rebaudiana-A magical sweetener. Global J. Biotech. \& Biochem. 5(1): 62-74.

[117] Mizutani, K. and O. Tanaka, 2002. Use of Stevia rebaudiana sweeteners in Japan. In: Kinghorn AD (ed), Stevia, the genus stevia. Medical and Aromatic Plants-Industrial Profile, Landon and NY: Taylor and Francis, 178-195.

[118] Muanda, F.N., R. Soulimani, B. Diop and A. Dicko, 2011. Study on chemical composition and biological activities of essential oil and extracts from Stevia Rebaudiana Bertoni leaves. LWT-Food Sci. \& Technol. 44(9): 1865-1872.

[119] Murphy, O., 2001. Non-polyol low-digestible carbohydrates: food applications and functional benefits. British J. Nutr. 85(51): 547-553.

[120] Newell-McGloughlin, M., 2008. Nutritionally improved agricultural crops. Plant Physiol. 147: 939-953.

[121] Ng, M, T. Fleming, M. Robinson, B. Thomson, N. Graetz, C. Margono and R. Gupta, 2013. Global, regional, and national prevalence of overweight and obesity in children and adults during 1980-2013: a systematic analysis for the Global Burden of Disease Study, The Lancet. 2014. 
[122] Oddone, B., 1999. How to grow Stevia. Technical manual. Guarani Botanicals, Pawtucket (United States). 130 p.

[123] Okada, M., Y. Soda, F. Hayashi, T. Doi, J. Suzuki, K. Miura and K. Kozai, 2005. Longitudinal study of dental caries incidence associated with Streptococcus mutans and Streptococcus sobrinus in pre-school children. J. Med. Microbiol. 54(7): 661-665.

[124] Parejo, I., F. Viladomat, J. Bastida, A. Rosas-Romero, N. Flerlage, J. Burillo and C. Codina, 2002. Comparison between the radical scavenging activities and antioxidant activity of six distilled and non distilled maditerranean herbs and aromatic plants. J. Agric.Food. Chem. 50: 6882-6890.

[125] Park, J.E. and Y.S. Cha, 2010. Stevia rebaudiana Bertoni extract supplementation improves lipid and carnitine profiles in C57BL/6J mice fed a high- fat diet. J. Sci. Food \& Agri. 90(7): 1099-1105.

[126] Paul, S., S. Sengupta, T.K. Bandyopadhyay and A. Bhattacharyya, 2012. Stevioside induced ROS-mediated apoptosis through mitochondrial pathway in human breast cancer cell line MCF-7. Nutri. \& Can. 64(7): 1087-1094.

[127] Pearson, R.L., 2001. Saccharin. In: O'Brien NL (ed), Alternative Sweeteners: Third Edition, Revised and Expanded. Marcel Dekker, New York: pp: 147-165.

[128] Pedroza Carneiro, J.W., 2007. Stevia rebaudiana (Bert.) Bertoni: Stages of plant development. Canadian J. Plant Sci. 87(4): 861-865

[129] PMAS, 2013.Pakistan Sugar Mill Association, 2013.48th Annual Meeting. In: Chairman Annual review. Pakistan Sugar Mills Association, Islamabad. Available at: http://www.psmacentre.com/aboutus.php?id=6andtype=annual_reviewandstatus=1

[130] Pol, J., B. Hohnová and T. Hyötyläinen, 2007.Characterisation of Stevia Rebaudiana by comprehensive two-dimensional liquid chromatography time-of-flight mass spectrometry. J. Chromato. A 1150(1): 85-92.

[131] Prakash, G., Dubois, J. Clos, K. Wilkens and L. Fosdick, 2008. Development of rebiana, a natural, non-caloric sweetener. Food Chem. Toxicol. 46: 575-582.

[132] Puri, M., D. Sharma and A.K. Tiwari, 2011. Downstream processing of stevioside and its potential applications. Biotech. AdvanC. 29(6): 781-791.

[133] Qing, Y., 2010. Gain Weight by ' Going diet?'Artificial sweetners and the neurobiology of sugar cravings. Yale J. Biol. Med. 83(2):101-08

[134] Rafiq, M., M.U. Dahot, S.M. Mangrio, H.A. Naqvi and I.A. Qarshi, 2007. In vitro clonal propagation and biochemical analysis of field established Stevia Rebaudiana Bertoni. Pak. J. Bot, 39(7), 2467-2474.

[135] Rajab, R., C. Mohankumar, K. Murugan, M. Harish and P.V. Mohanan, 2009. Purification and toxicity studies of stevioside from Stevia Rebaudiana Bertoni. Toxicol Int. 16: 49-54.

[136] Ramesh, K., S. Virendra and W.M. Nima, 2006. Cultivation of Stevia [Stevia rebaudiana (Bert.) Bertoni]: A Comprehensive Review." Advanc. Agro. 89: 137-177.

[137] Raskovic, A., Jakovijevic, M. Mikov and M. Gavrilovic, 2004. Joint effect of commercial preparations of Stevia Rebaudiana Bertoni and sodium monoketocholate on glycemia in mice. European J. Drug. Metab. Pharmaco. 29(2): 3-86.

[138] Sabah, A.H. and M.A.K. Rasha, 2013. Biotechnological studies for improving of stevia (Stevia Rebaudiana Bertoni) in vitro plantlets. Middle-East J. Sci. Res. 14: 93-106

[139] Salim, M.U., M.H.C. Shaheed, M.M.K. Mouoztaba, M.U. Belal, R. Ahmed and M.A. Baten, 2006. In vitro propagation of Stevia Rebaudiana Bert in Bangladesh. Afr. J. Biotechnol. 5: 1238- 1240.

[140] Savita, S.M., K. Sheela, S. Sharan, A.G. Shankar, P. Ramakrishna and S. Sakey, 2004b. Health implications of Stevia Rebaudiana. J. Hum. Ecol. 15:191-194.

[141] Savita, S.M., K. Sheela, S. Sunanda, A.G. Shankar and P. Ramakrishna, 2004a.Stevia Rebaudiana-A functional component for food industry. J. Hum. Ecol 15(4): 261-264.

[142] Schreiber, A.S., 2010. Characterization and isolation of glycosides of Stevia rebaudiana. Ph.D Thesis (unpublished). Facul. of Life Sci., Uni. of Vienna, Austria.

[143] Sehar, I., A. Kaul, S. Bani, H.C. Pal and A.K. Saxena, 2008. Immune up regulatory response of a non-caloric natural sweetener, stevioside. Chem. Biolo, Interac. 173(2): 115-121.

[144] Sekihashi, K., H. Saitoh and Y. Sasaki, 2002. Genotoxicity studies of stevia extract and steviol by the comet assay. J. Toxicol. Sci. 27:1-8.

[145] Serio, L., 2010. Stevia Rebaudiana; an alternative sugar. Phytotherapy 2010; 8(1): 26-32.

[146] Sharma, D., M. Puri, A. Tiwari, N. Singh and A. Jaggi, 2010. Anti-amnesic effect of Stevioside inscopolamine treated rats. Ind. J. Pharmacol. 2010; 42(3):164-167.

[147] Shiozaki, K., A. Fujii, , T. Nakano, , T. Yamaguchi and M. Sato, 2006. Inhibitory effects of hot water extract of the Stevia stem on the contractile response of the smooth muscle of the guinea pig ileum. Biosco. Biotechnol. Biochem. 70: 489494. 
[148] Shivanna, N., M. Naika, F. Khanum and V.K. Kaul, 2013. Antioxidant, anti-diabetic and renal protective properties of Stevia Rebaudiana. J. Diab. Comp. 27(2): 103-113.

[149] Siddique, A.B., S.M. M.izanur Rahman and M. A.mzad Hossain, 2012. Chemical composition of essential oil by different extraction methods and fatty acid analysis of the leaves of Stevia Rebaudiana Bertoni. Arabian J. Chem. 10: 10-16

[150] Siddique, A.B., S.M.M. Rahman, M.A. Hossain, M.A. Hossain, and M.A. Rashid, 2014. Phytochemical screening and comparative antimicrobial potential of different extracts of Stevia Rebaudiana Bertoni leaves. Asian Pac. J. Trop. Dis. 4(4): 275-280.

[151] Silvia, T. and G.A. Luciana, 2013. Stevia Rebaudiana Bertoni as a source of bioactive compounds: the effect of harvest time, experimental site and crop age on steviol glycoside content and antioxidant properties. J. Sci. Food Agric. 93: 21212129

[152] Singh, S.D. and G.P. Rao, 2005.Stevia :the herbal sugar of 21st Century. Sugar Tech. 7(1): 17-24.

[153] Sivaram, L. and U. Mukundan., 2003. In vitro culture studies on Stevia Rebaudiana. In vitro Cell. Dev. Biol. 39(5): 520523.

[154] Small, E., P.M. Catling and H. Daubeny, 2001. BLOSSOMING TREASURES OF BIODIVERSITY: 1. Stevia (Stevia rebaudiana (Bertoni) Bertoni)—-how sweet it is!. Biodiver. 2(2); 22-23.

[155] Soejarto, D.D., 2002. Botany of Stevia and Stevia Rebaudiana. In: Kinghorn AD (ed), Stevia: The Genus Stevia. Taylor and Francis, London: pp:18-39.

[156] Stancik, A. and M. Scholar, 2005. Coupled green Extraction of Diterpene Glycosides in Stevia rebaudiana Bertoni. McNair Res. J. 1: 58-65

[157] Stoyanova, S., J. Geuns, E. Hideg and W. Van Den Ende, 2011. The food additives inulin and stevioside counteract oxidative stress. Int. J. Food Sci. \& Nutr. 62(03): 207-214.

[158] Tadhani, M.B., V.H. Patel and R. Subhash, 2007. In vitro antioxidant activities of Stevia Rebaudiana leaves and callus. J. Food Comp. \& Anal. 20(3-4): 323-329.

[159] Tadhani, M.B. and R. Subhash, 2006. In vitro antimicrobial activity of Stevia Rebaudiana Bertoni leaves. Trop. J. Pharm. Res. 5(1): 557-560.

[160] Takahashi, K., M. Matsuda, K. Ohashi, K. Taniguchi, O. Nakagomi, Y. Abe and S. Shigeta, 2001. Analysis of antirotavirus activity of extract from Stevia Rebaudiana. Antiviral Res. 49: 15-24.

[161] Talha, M., I. Hussain, R. Ullah and L. Khan, 2012.Analysis of stevioside in Stevia Rebaudiana. J. Med. Plants Res. 6(11): 2216-2219.

[162] Tappy, L., K.A. Lê, C. Tran and N. Paquot, 2010. Fructose and metabolic diseases: new findings, new questions. Nutri. 26(11): 1044-1049.

[163] Taware, A.S., S.N. Harke, D.S. Mukadam, A.M. Chavan and S.D. Taware, 2010. Effect of different extracts of callus and plantlets of Stevia Rebaudiana (Bertoni) on seed germination of some agricultural crops. African J. Biotech. 9(40): 66756683.

[164] Taware, A.S., D.S. Mukadam, A.M. Chavan and S.D. Tawar, 2010. Comparative studies of in vitro and in vivo grown plants and callus of Stevia Rebaudiana (Bertoni. Inter. J. Integr. Biol. 9: 10-15.

[165] Thiyagarajan, M. and P. Venkatachalam, 2012. Large scale in vitro propagation of Stevia rebaudiana (bert) for commercial application: Pharmaceutically important and antidiabetic medicinal herb. Indus. Crops Prod. 37(1): $111-117$.

[166] Thylstrup, A. and O. Fejerskov, 1994. Textbook of clinical cardiology. 2nd Ed. Wiley-Blackwell, Munksgaard, Copenhagen, Denmark.

[167] Tomita, T., N. Sato, T. Aria, H. Shiraishi, M. Sato, M. Takeuchi and Y. Kamio, 1997. Bactericidal activity of a fermented hot water extract from Stevia Rebaudiana Bertoni towards enterohaemorrhagic Escherichia Coli 0157:H7 and other food borne pathogenic bacteria. Microbiol. Immunol. 41: 1005-1009.

[168] Ulbricht, C., R. Isaac, T. Milkin, E.A. Poole, E. Rusie, J.M. Grimes Serrano, W. Weissner and R.C. Wonder, 2010. An evidence based systematic review of stevia by the Natural Standard Research Collaboration. Cardiovasc. Haematol. Agents Med. Chem. 8(2): 113-27.

[169] Valko, M., D. Leibfritz, J. Moncol, M.T. Cronin, M. Mazur and J. Telser, 2007.Free radicals and antioxidants in normal physiological functions and human disease. Int. J. Biochem. \& Cell Boil. 39(1): 44-84.

[170] Vartanian, I.R., M.B. Schewartz and K.D. Brownel, 2007. Effect of soft drink consumption on nutrition and health: a systematic review and meta - analyziz. American J. Publ. Health 97(4): 667- 675.

[171] Vasanti, M., 2010.Suger-sweeted beverage and risk of metabolic syndrome and type 2diabetes:Ameta analyziz. Diab. Care 33(11): 2477-2483.

[172] Vitery, G., S. Vargas, F. Gamboa, N. Chavarría and R. Góme, 2010. Actividad inhibitoria de Stevia Rebaudianabertoni sobre Lactobacillus acidophillus y Streptococcus mutans. Rev. Nal. Odo. 6: 57-64. 


\section{American Research Journal of Agriculture, Volume 1, Issue 1, February 2015}

ISSN 2378-9018

[173] Wallin, H., 2007. Steviol glycosides. 63rd Joint FAO/WHO Expert Committee on Food Additives (JECFA) - Chemical and Technical Assessment (CTA), 1-7.

[174] Wheeler, A., A.C. Boileau, P.C. Winkler, J.C. Compton, I. Prakash, X. Jiang, et al., 2008. Pharmacokinetics of rebaudioside A and stevioside after single oral doses in healthy men. Food Chem. Toxicol. 46(7): 554-560.

[175] Williams, L.D. and G.A. Burdock, 2009. Genotoxicity studies on a high-purity rebaudioside A preparation. Food Chem. Toxicol. 47(8): 1831-1836.

[176] Woelwer-Rieck, U., C. Lankes, A. Wawrzun and M. Wüst, 2010. Improved HPLC method for the evaluation of the major steviol glycosides in leaves of Stevia rebaudiana. European Food Res. Technol. 231(4): 581-588.

[177] Wolwer-Rieck, U., W. Tomberg and A. Wawrzun, 2010.Investigations on the stability of Stevioside and Rebaudioside A in soft drinks. J. Agri. Food Chem. 58: 12216-12220.

[178] Wolwer-Rieck, U., 2012. The leaves of Stevia Rebaudiana (Bertoni), their constituents and the analyses thereof: a review. J. Agri. Food Chem. 60: 886-895.

[179] Yadav, A.K., S. Singh, D. Dhyani and P.S. Ahuja, 2011. A review on the improvement of stevia [Stevia rebaudiana (Bertoni)]. Canadian J. Plant Sci. 91(1): 1-27.

[180] Yadav, S.K. and P. Guleria. 2012. Steviol glycosides from Stevia: biosynthesis pathway review and their application in foods and medicine. Crit. Rev. Food Sci. \& Nutr. 52(11): 988-998.

[181] Yasukawa, K., S. Kitanaka and S. Seo, 2002.Inhibitory effect of stevioside on tumor promotion by 12-Otetradecanoylphorbol13-acetate in two-stage carcinogenesis in mouse skin. Biol. Pharm. Bull. 25(11): 1488-1490.

[182] Yu, C. and Y. Shi (2009. Determination methods of stevioside. Sugar Crops China 1: 65-67.

[183] Zaidan, L.B.P., S.M.C. Dietrich and G.M. Felippe, 1980. Effect of photoperiod on flowering and stevioside content in plants of Stevia Rebaudiana Bertoni. Jap. J. Crop Sci. 49: 569-574.

[184] Ziegler, D., 2005. Treatment of diabetic neuropathy and neuropathic pain. Diab. Care 31(2): 5255-5261. 